\title{
Regulatory Reform and the U.S.
} Manufacturing Sector THE FOCUS IS ON IMPROVING EFFICIENCY

\author{
By Thomas A. Hemphill
}

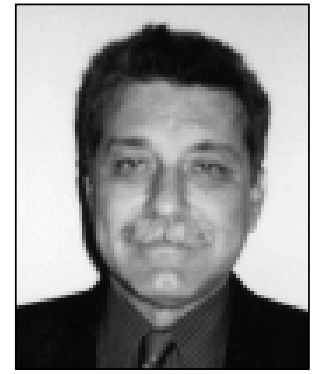

Thomas A. Hemphill is assistant professor of strategy, innovation and public policy at the University of Michigan-Flint. He earned his Ph.D. in business administration, with a primary field in strategic management and public policy and a secondary field in technology and innovation policy from The

George Washington University.

The Bush administration, through the Office of Management and Budget, Office of Information and Regulatory Affairs (OMB/OIRA), has shown renewed interest in regulatory reform as an important public issue, especially as it pertains to the nation's manufacturing sector. On March 9, 2005, OMB/OIRA announced that Federal agencies will be taking practical steps of an administrative nature to reduce the cost burden on manufacturing firms operating in the United States by acting on 76 suggested reforms of federal regulations suggested by the public. Recommended actions range from gathering and reporting additional information to issuing modernized regulations, with reforms to be implemented through rulemaking procedures that include an opportunity for public participation.

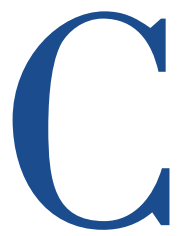
oncerns about the declining economic health of the U.S. manufacturing sector in the global economy, especially with regard to this sector's ability to generate net employment, has been public fodder for business economists and industry analysts. Most recently, this sentiment was succinctly expressed by the President's Council of Economic Advisers:

The manufacturing sector was affected by the latest economic slowdown earlier, longer, and harder than other sectors of the economy and only recently have manufacturing losses begun to abate. Over the past several decades, the manufacturing sector has experienced substantial output growth, even while manufacturing employment has declined as a share of total employment (Council of Economics Advisers, 2004).

According to the U.S. Department of Commerce, output fell six percent in U.S. manufacturing from 2000 to May 2003 (when the manufacturing recession ended), even though the general recession was relatively shallow overall. Furthermore, employment fell by 2.6 million jobs in manufacturing, accounting for all of the net job losses from the fourth quarter of 2000 through the third quarter of 2003 (U.S. Department of Commerce, 2004). The indirect effects of manufacturing sector changes can be more widespread in the economy, including impacts on consumers or suppliers in the form of higher or lower prices and impacts to employment trends to the extent that man- 
ufacturing employment experiences higher productivity gains than other sectors (Council of Economic Advisers, 2004). In spite of the Council of Economic Advisers' lessthan-optimistic appraisal of its economic performance, the manufacturing sector still accounts for 14 percent of U.S. GDP (Yuskavage and Strassner, 2003) and 11 percent of total U.S. employment (U.S. Department of Commerce, 2004).

The Bush administration has not been oblivious to the manufacturing sector's economic woes. In a March 2003 speech to the National Association of Manufacturers (NAM) in Chicago, Illinois, then Secretary of Commerce Donald Evans announced his agency's Manufacturing Agenda, which established clear policy prioritiesincluding pro-growth tax policies, free and fair trade, and education and health care reform-to enhance economic growth and create higher paying employment in the manufacturing sector (U.S. Department of Commerce, 2003). To implement the Manufacturing Agenda, a complementary manufacturing initiative was instituted to answer the ultimate question: What federal government actions help or hinder American manufacturers as they compete in global markets? To that end, Evans directed his staff to seek policy input from American manufacturers to identify the root causes of the manufacturing sector's current challenges and the specific obstacles that government policy might pose to U.S. manufacturing competitiveness (U.S. Department of Commerce, 2004). What became apparent to Commerce staff (as this initiative was implemented) is American manufacturers' concerns over the ever-growing burden of regulatory costs that the manufacturing sector must absorb in global competition - an item not included on the Bush administration's original Manufacturing Agenda.

\section{The Regulatory Burden on the U.S. Manufacturing Sector}

In order to establish a common point of analytic departure, this section will provide a brief review of regulation in the United States, particularly as it affects manufacturing. Ostensibly, regulation is undertaken to enhance society's general welfare. The means to this end is to limit the choices available to individuals, corporations, and sub-governments (Mitnik, 1980). This limitation of choice includes (in the case of anti-monopoly regulation) maintaining choices available to some segments of the economy by restricting choices available to others and rectifying harms caused by externalities (such as industrial pollution).

The American business community is confronted by two primary forms of regulation. The first form, economic regulation, controls prices or wages, allocates public resources, establishes service territories, sets the number of participants, and rations resources. This form of business regulation has its antecedents in 19th century America and was originally applied to specific industries exhibiting monopoly power (e.g., communications, electric utilities, and transportation). The second form, social regulation, is concerned with environmental protection, employee and consumer safety, employment discrimination, and public health. This form of regulation is processoriented, has cross-industry applications, and has its genesis in legislation enacted by the U.S. Congress in the 1970s. A third type of regulation involves paperwork to document compliance for payment of taxes and fees. Although this type of regulation has much less impact on direct business operations, it involves significant expense. In 1997, the Office of Management and Budget (OMB) calculated that the cost of business compliance with federal regulation made up 3.7 percent of U.S. GDP in 1997 (U.S. Department of Commerce, 2004).

The government's regulatory burden on specific economic sectors of the U.S economy was recently studied by Hopkins and Crain (2001) for the U.S. Small Business Administration. Using data collected for 1997, Hopkins and Crain estimated the economic impact of four types of regulation-economic, social (divided into environmental and workplace rules), and tax compliance-on different sectors of the U.S. economy, including manufacturing.

Hopkins and Crain used three metrics to ascertain regulatory burden: the overall burden in the manufacturing sector, the burden per firm in the manufacturing sector, and the burden per employee in the manufacturing sector. Their study results show that on a per-firm basis manufacturers face regulatory costs approximately six times greater ( $\$ 147$ billion annually, or a cost per employee of $\$ 7,904)$ than the average firm in the U.S. economy. When adjusted for the number of employees (a manufacturing firm has an average payroll three times greater than the average firm), a manufacturing firm faces a regulatory cost per employee approximately twice that of the average firm. Significantly, the cost of compliance with such rules falls hardest on businesses with fewer than 20 employees. According to Hopkins and Crain, small manufacturing businesses reported that compliance with regulation amounted to a cost of $\$ 16,920$ per employee. For larger manufacturing firms (over 500 employees), the cost of compliance dropped by more than half, to $\$ 7,454$ per employee. Furthermore, the study results reveal that environmental regulations are the biggest regulatory burden on manufacturing (nearly 50 percent of the total cost, or a cost per employee of $\$ 3,691$ ), followed by economic regulations, tax compliance, and workplace rules, which 
Environmental regulations are the biggest regulatory burden on manufacturing (nearly 50 percent of the total cost).

include categories such as employee benefits, occupational safety and health rules, and labor standards. Consequently, the costs of non-environmental regulations-workplace, economic, and federal tax compliance-for the trade and services sectors is approximately equal to that of the manufacturing sector (as the allocation of environmental regulatory costs by Hopkins and Crain to the trade [0 percent] and services [ 1 percent] sectors of the U.S. economy is of no consequence).

More recently, Leonard (2003) completed a regulatory cost study for NAM. According to the NAM study, the total burden of environmental, economic, workplace, and tax compliance is $\$ 160$ billion annually on the manufacturing sector, equivalent to a 12-percent excise tax on manufacturing production. The results of this study reflect an increase in the manufacturing regulatory burden of nearly 15 percent in the last five years, which, since regulatory compliance costs are rising faster than income in the manufacturing sector, implies a loss of cost competitiveness, or, at a minimum, a negative offset to the benefits of the extraordinary productivity gains and efforts by manufacturers to cut costs under their direct control (U.S. Department of Commerce, 2004, p. 43).

Recent American business (including manufacturers) concerns with the burden of regulatory paperwork have centered on the cost of complying with the SarbanesOxley Act of 2002 and New York Stock Exchange/NASDAQ listing requirements, specifically provisions in Section 404 of Sarbanes-Oxley, which focus on internal controls and enhanced financial disclosures. The Business Roundtable "Third Annual Survey of Corporate Governance Practices" asked its corporate members about the costs incurred in connection with the SarbanesOxley Act and New York Stock Exchange/NASDAQ listing requirements (Business Roundtable, 2005). Survey respondents gave these projections:

- 47 percent estimated costs of more than $\$ 10$ million (up from 22 percent in 2004).

- 29 percent estimated costs between $\$ 6$ and $\$ 10$ million.

- 23 percent estimated costs between $\$ 1$ million and $\$ 5$ million.
Even if Hopkins and Crain (2001) are guilty of overstating regulatory costs on the U.S. manufacturing sector, the ratios of these costs to other sectors of the U.S. economy (6:1 versus the average firm, and 2:1 adjusted for employment), paint a stark economic landscape for U.S. manufacturers attempting to compete in a global economy where many other countries' manufacturing sectors have lower total costs of production. ${ }^{1}$ Thus, it comes as no surprise that U.S. manufacturers, representing a broad spectrum of companies and industry associations, provided valuable input into regulatory reform policy recommendations for the Bush administration's manufacturing initiative.

\section{The Manufacturing Initiative and the Regulatory Reform Agenda}

In January 2004, the U.S. Department of Commerce publicly released Manufacturing in America: A Comprehensive Strategy to Address the Challenges to U.S. Manufacturers. Of the six areas that manufacturers attending the Commerce Department's 20 nationwide roundtables identified as needing immediate attention, reducing the regulatory costs that government imposes on manufacturing made the list. To address this issue of reducing the rising costs of regulatory compliance, Manufacturing in America recommended that OMB should lead the following three-step process to reduce the burden of regulation on the U.S. manufacturing sector:

- Establish an inventory of potential regulatory reforms that would lower the cost of manufacturing. OMB should seek public comment on existing rules and afford the opportunity to propose particular reforms. The request for public comment and the nomination of reforms should address existing regulations, guidance documents, and paperwork requirements.

- Conduct an analysis of the inventory. OMB should, in consultation with the Council of Economic Advisers, the Commerce Department, and other agencies, evaluate the proposed reforms and, where appropriate, implement those reforms on a priority basis. This evaluation should include an assessment of the cost of compliance and the economic impact of current rules, particularly on small and medium-sized businesses, as well as the cost to the taxpayer and to the consumer of administering those regulations. The objective of the review should be to determine whether there is a

\footnotetext{
${ }^{1}$ As Leonard (2003) found in his study results, external overhead costs (i.e., corporate tax rate, employee benefits, tort costs, natural gas costs, and pollution abatement expenses) add at least 22.4 percent to unit labor costs of U.S. manufacturers (nearly $\$ 5.00$ per hour worked) relative to their major foreign competitors. Note that this is the relative, not the absolute, burden of external overhead costs.
} 
less costly means of achieving the benefits Congress intended by authorizing such regulations. That analysis should extend to the agencies that implement the rules as well. This effort could involve broadening the analysis done under section 610 of the Regulatory Flexibility Act, which currently applies to small business.

- Conduct a regulatory impact analysis of new rules. Lastly, OMB should rigorously apply its recently developed guidance on regulatory impact analysis to any proposed rules that would influence the costs imposed on the manufacturing sector, particularly as they affect small and medium-sized businesses. As a part of this effort, the newly established assistant secretary for manufacturing and services in the Department of Commerce should task the new Office of Industry Analysis to work with OMB and other agencies to refine the analytic tools needed to assess the impact of proposed rules and regulations on economic growth and job creation in the manufacturing sector and other areas of the economy.

Following the issuing of the Manufacturing in America report, the OMB announced on February 13, 2004 its intentions to implement the first recommendation to establish an inventory of potential regulatory reforms that would lower the cost of manufacturing. To that end, OMB sought public comment on manufacturing regulations in need of modernization to reduce costs, increase effectiveness, and enhance the competitiveness of U.S. manufacturers (Office of Management and Budget, 2004). It should be noted that the OMB's request for nominations of regulatory reforms was directed to those that can be implemented through administrative action, and not legislative recourse.

In response to OMB's request for public nominations of promising regulatory reforms (concerning rules, guidance documents, or paperwork requirements) relevant to the manufacturing sector, the office received 189 distinct nominations that would improve manufacturing regulation by reducing unnecessary costs, increasing effectiveness, enhancing competitiveness, reducing uncertainty, and increasing flexibility, from 41 respondents. ${ }^{2}$ Of these 189 reform nominations, nearly 50 percent (94) concerns rules under the authority of the U.S. Environmental Protection Agency (EPA).

Not surprisingly, the overwhelming majority of the regulatory reform nominations are submitted by corporations or industry associations, although other special interest

2The U.S. Small Business Administration (2004) submitted 19 of these regulatory reform proposals to reduce the regulatory burden on businesses with fewer than 500 employees. groups, including Public Citizen and People for the Ethical Treatment of Animals, submitted several nominations.

On March 9, 2005, OMB announced that Federal agencies (the Departments of Treasury, Agriculture, Commerce, Labor, Health and Human Services, Transportation, and Homeland Security, as well as the Environmental Protection Agency) will be taking practical steps to reduce the cost burden on manufacturing firms operating in the United States by acting on 76 of the submitted public nominations to reform federal regulations (Office of Management and Budget, 2005a). Recommended actions range from gathering and reporting additional information to issuing modernized regulations, with reforms implemented through rulemaking procedures that include an opportunity for public participation.

Examples of a few of these accepted OMB regulatory reform proposals focused on reducing environmental paperwork costs for manufacturers and include (Office of Management and Budget, 2005b):

- The EPA is charged with investigating the reporting and paperwork burden in the Toxic Release Inventory (TRI) Program. The required TRI database contains thousands of reports that show little or no release of toxic chemicals, an indication that expensive and time-consuming reports are required with little environmental benefit. Burden-reduction reforms will be considered, such as raising the reporting thresholds on the amount of material that can be used without triggering a report.

- The EPA will investigate lead reporting burdens under the TRI program. The 2001 rule adding lead and lead compounds to the list of persistent, bioaccumulative, and toxic chemicals caused a lowering in the annual reporting threshold for lead from 10,000 to 100 pounds of use per year. The result has been that thousands of small manufacturers must file Form $\mathrm{R}$ to the federal government, even though their emissions of lead into the environment are minor or even zero. EPA will re-examine the justification for lowering the reporting threshold and the 2001 rule for possible amendment to reduce the substantial paperwork burden on small lead emitters.

- The EPA will study the high cost of export notification requirements. Companies are required to notify EPA when exporting substances or products that contain chemicals listed on the Export Notification 12(b) list under the Toxic Substances Control Act; 15 U.S.C. s/s 2601 et seq. Since current rules do not have a low-level cutoff, many minor substance or product ingredients trigger large volumes of paperwork. To reduce this burden, a low-level cutoff will be 
considered for addition to 12(b).

- The EPA will research concerns that manufacturers have with electronic filing. The agency, in collaboration with state regulators who administer federal air quality rules, will consider developing and implementing user-friendly, multi-media electronic filing systems as a means of reducing the paperwork burden on manufacturers. Encouraging commonality of forms and electronic filing procedures, coupled with use of compatible software between state and federal regulators, is essential to regulatory burden reduction.

According to John D. Graham, director of the Office of Information and Regulatory Affairs (OIRA) ${ }^{3}$ within OMB, the unit responsible for implementing this initiative:

Manufacturers incur a larger share of regulatory costs than other sectors of the economy, and these reforms can be undertaken while retaining the benefits of regulation to consumers, workers, and the environment. By reducing the costs of operating businesses in the United States, these reforms help make businesses more productive while protecting American jobs (Office of Management and Budget, 2005a).

\section{The Regulatory Reform Outlook for Manufacturers}

There is an optimistic view among manufacturing sector advocates that the OMB/OIRA regulatory reform initiative will bring some overdue relief to a long beleaguered sector of the American economy. During the second Bush administration, there is renewed policy emphasis on improving effectiveness and efficiency in federal regulation of the economy-especially in heavily regulated sectors such as manufacturing (Skrzycki, 2005a). House Majority Leader Tom Delay (R-TX) is on record that "universal regulatory reform", which would apply to all federal agencies, is a key priority for House Republicans (Kerrigan, 2005).

The OIRA is investigating legislation that would allow judicial review of agency decisions made under the law.

\footnotetext{
${ }^{3}$ The U.S. Congress established OIRA under the 1980 Paperwork Reduction Act. In addition to reviewing draft regulations under Executive Order 12886, OIRA reviews collections of information under the Paperwork Reduction Act and develops and oversees the implementation of government-wide policies in the areas of information technology, information policy, privacy, and statistical policy (Office of Management and Budget, 2002). Since Graham's office first requested rules for review (early in the first term of the Bush administration), it has received 576 nominations (mostly from business groups) with federal agencies acting on 135 nominations with proposals or final rules (Skrzycki, 2005a).
}

The Bush administration has

renewed emphasis on improving

effectiveness and efficiency in

federal regulation of the

economy-especially in heavily

regulated sectors such as

manufacturing

This review would allow outside parties to challenge the data agencies use in rulemaking. Furthermore, there is discussion in the Bush administration of turning some of the principles in presidential executive orders, such as cost-benefit analysis, into laws. "It would make it more difficult for a new president to come in and get rid of the [present] regulatory review process," said Lawrence A. Fineran, vice president of regulatory and competition policy for NAM (Skrzycki, 2005a).

Already, U.S. Representative Christopher Norwood (R-GA) has re-introduced four bills (HR 739, HR 740, HR 741, and HR 742) in the 109th Congress, each bill offering a separate reform of the Occupational Safety and Health Administration (OSHA), U.S. Department of Labor (Norwood, 2005). These four workplace safety reform bills passed the House with bipartisan support but were subsequently blocked in the U.S. Senate. All four bills are focused on providing small businesses, and especially small manufacturers, with cost-saving remedies, including allowing for more time to respond to OSHA charges (HR 739), the right to a speedy administrative trial (HR 740), the right of appeal to an independent court (HR 741), and ending OSHA's perceived overzealousness in pursuing judicial remedies (if the business owner shows that OSHA charges are frivolous, OSHA has to pay all court costs and attorney fees of the business).

In the U.S. House of Representatives, the new chair of the House Government Reform Subcommittee, Representative Candice S. Miller (R-Michigan), has been meeting with business groups discussing what they describe as their regulatory burdens. Her first hearing, held on April 12, 2005, focused on the regulatory burden carried by U.S. manufacturing, an industry sector that has been declining in her home state, as well as the Bush administration's initiative to support the manufacturing sector (Skrzycki, 2005b).

At the April 12, 2005 House Government Reform Subcommittee hearing, Albert Frink, the U.S. Department 
of Commerce assistant secretary for manufacturing and services, urged that the list of regulatory reform measures be expanded to include the Sarbanes-Oxley Act of 2002, citing this as the most onerous requirement for the manufacturing sector (OMB Watch, 2005). However, rules implementing Sarbanes-Oxley do not appear as one of the 76 chosen regulatory reforms. Also at this hearing, Representative Stephen Lynch (D-MA), the ranking minority member of the House Government Reform Subcommittee, expressed his position that regulatory reform measures should reflect the interests of all stakeholders and not just those of big business (OMB Watch, 2005). Lynch called for a balanced regulatory reform plan that should address not only excessive costs, but also the need for increased public protections.

After a hiatus, regulatory reform is re-emerging as an important public issue, especially as it pertains to as heavily a regulated industry sector as manufacturing. There is also much stronger bipartisan support for small business (fewer than 500 employees), and narrowly tailored regulatory reform legislation focusing on small manufacturing firms will receive a warmer reception in Congress. A chronic problem regarding federal business regulations is that few of them are ever evaluated to determine whether they have successfully met their intended legislative charge and what their actual costs and benefits have been. Under Graham's leadership, the OIRA has instituted both a high level of cost-benefit analyses and science-based risk assessment applied to regulatory proposals advanced by federal agencies. For example, in its recent draft Report to Congress on the Costs and Benefits of Federal Regulations (Office of Management and Budget, 2005c) (implementing the Regulatory Right-to-Know Act), the OIRA included a 10year quantified and monetized review of the costs and benefits of major federal regulations and recommendations for regulatory reform.

For the U.S. manufacturing sector, federal agencies and the OMB-OIRA will now have a second chance under this latest regulatory reform initiative to evaluate and, where appropriate, improve the efficacy and efficiency of many long-established rules governing manufacturers' operations - while simultaneously safeguarding the public health, worker safety, and the natural environment. This is a formidable challenge indeed, but one long overdue.

\section{A C K N OW LED G EM EN T}

I wish to thank two anonymous referees and the editor for helpful comments in the preparation of this paper.

\section{REF ER E N C ES}

Business Roundtable. 2005. "Business Roundtable Corporate Governance Survey: Key Findings.” March; http://www.businessroundtable.org, accessed March 16, 2005.

Council of Economic Advisers. 2004. Economic Report of the President. Washington, D.C.

Hopkins, Thomas and Crain, W. Mark. 2001. The Impact of Regulatory Costs on Small Firms, Report No. PB2001-107067. U.S. Small Business Administration, Office of Advocacy, Washington, D.C.

Kerrigan, Karen. 2005. "What About Government Regulation?" January 20; http://www.sbsc.org/LatestNews_Action.asp?FormModes= SmallBusBriefs, accessed February 14, 2005.

Leonard, Jeremy A. 2003. How Structured Costs Imposed on U.S. Manufacturers Harm Workers and Threaten Competitiveness. Washington, D.C.: National Association of Manufacturers.

Mitnick, Barry M. 1980. The Political Economy of Regulation. New York: Columbia University Press.

Norwood, Charles. 2005. "Norwood Reintroduces 4 OSHA Reform Bills: Isakson Promises Senate Subcommittee Action." Office of Congressman Charles Norwood, 9th District, Georgia, News Release, Washington, D.C. February 10.

Office of Management and Budget. 2002. "Questions and Answers about OIRA." February 26; http://www.whitehouse.gov/omb, accessed February 14, 2005.

—. 2004. "OMB Initiates Review of Manufacturing Regulations." Executive Office of the President of the United States, Press Release, Washington, D.C. February 13.

- 2005a. "OMB Acts to Curb Regulatory Burden on Manufacturing Sector." Executive Office of the President, Press Release, Washington, D.C. March 9.

- 2005b. Regulatory Reform of the U.S. Manufacturing Sector, Executive Office of the President of the United States, Washington, D.C. March.

- 2005c. Report to Congress on the Costs and Benefits of Federal Regulations, Executive Office of the President of the United States, Washington, D.C. March.

OMB Watch. 2005. "House Considers Anti-Regulatory Hit List." April 19; http://www.ombwatch.org/articleprint/2808/-1/309, accessed August 1, 2005.

Skrzycki, Cindy. 2005a. "Report Sheds Light on Changing Role of Regulation." The Washington Post. January 25, pp. E1 \& E6.

- 2005b. "Business Looks to Panel's New Leader for Relief.." The Washington Post. April 12; pp. E1 \& E4.

U.S. Department of Commerce. 2003. "Evans Launches Bush Administration's Manufacturing Agenda." March 5; http://www.commerce.gov/opa/press/Secretary_Evans/2003_Releases/March/05_Evans _Manufacturing_release.htm, accessed November 29, 2005.

2004. Manufacturing in America: A Comprehensive Strategy to Address the Challenges to U.S. Manufacturers. January; Washington, D.C.

Yuskavage, Robert E. and Erich H. Strassner. 2003. "Gross Domestic Product by Industry for 2002." Survey of Current Business. May, pp. 7-14. 